\title{
Pallidal Deep Brain Stimulation in a 5-Year-Old Child with Dystonic Storm: Case Report
}

\author{
Beş Yaşında Olan Distonik Furtına Vakasında Pallidal Derin Beyin \\ Stimülasyonu: Olgu Sunumu
}

\author{
Sabri AYDIN ${ }^{1}$, Bashar ABUZAYED ${ }^{1}$, Serap UYSAL ${ }^{2}$, Olcay UNVER ${ }^{2}$, Mustafa UZAN $^{1}$, Murat $^{4}$ MENGI $^{3}$, \\ Osman KIZILKILIC ${ }^{4}$, Murat HANCI ${ }^{1}$ \\ ${ }^{1}$ Istanbul University, Cerrahpasa Faculty of Medicine, Department of Neurosurgery, Istanbul, Turkey \\ ${ }^{2}$ Istanbul University, Cerrahpasa Faculty of Medicine, Department of Pediatrics, Division of Pediatric Neurology, Istanbul, Turkey \\ ${ }^{3}$ Istanbul University, Cerrahpasa Faculty of Medicine, Department of Physiology, Istanbul, Turkey \\ ${ }^{4}$ Istanbul University, Cerrahpasa Faculty of Medicine, Department of Radiology, Division of Neuroradiology, Istanbul, Turkey
}

Presented in: This case was presented as a discussion poster in the 25th Turkish Neurosurgery Society Scientific Congress 22-26 April, 2011. Antalya, Turkey.

Correspondence address: Bashar ABUZAYED / E-mail: sylvius@live.com

\begin{abstract}
A 5-year-old child had a medical history of epilepsy and a newly presented mental retardation with a life-threatening dystonic storm. Neuroimagings showed bilateral calcification of the pallidum. Several treatment modalities were performed, but the symptoms showed no significant improvement. The patient was operated on in order to place a deep brain stimulation (DBS) targeting bilateral globus pallidum internus (GPi). The dystonia showed a remarkable improvement after surgery, with $81 \%$ reduction of dystonia severity after 15 months. To our best knowledge, this is the youngest patient mentioned in the literature to be treated with DBS, which was also life-saving in this case.

KEYWORDS: Deep brain stimulation, Dystonia, Movement disorders, Pediatric neurology, Status dystonicus

öz

Beş yaşında erkek ve epilepsi hikayesi olan hasta akut başlayan generelize status distonikus (distonik fırtına) ile başvurdu. Tüm vücuduna zarar veren hastaya midozolam infüzyonu tedavisi uygulandı. Kranyal BT ve MR'da bilateral putamen kalsifikasiyonu vardı. Hastanın FahnMarsden Skoru 106 olarak bulundu ve tüm medikal tedavi yöntemlerine dirençli idi. GPi hedeflenerek iki taraflı derin beyin stimülasyonu (DBS) yerleştirilmesi ameliyatı yapıldı. Ancak hastanın yaşının küçük olması ve kafa büyümesinin devam edeceği düşünülerek elektrot ucu hedefin 1 $\mathrm{cm}$ inferioruna yerleştirildi. Postop dönemde komplikasyon görülmeyen hastanın şikayetleri azaldı. Ameliyat sonrası 15. ay kontrolünde hasta destekli oturuyordu, oral alımı düzelmişti ve kooperasyonu artmıştı. Fahn-Marsden Scoru 20 bulundu (total skoru \% 81 azalmıştır). Literatürde tarif edilen en küçük yaşta DBS uygulanmış hasta olup bu yaş grubunda hayat kurtarıcı "acil” DBS kullanımını sunmaktayız.
\end{abstract}

ANAHTAR SÖZCÜKLER: Derin beyin stimülasyonu, Distoni, Hareket bozukluğu, Pediatrik nöroloji, Status distonikus

\section{INTRODUCTION}

A dystonic storm, or status dystonicus, is defined as a progressively increasing frequent and severe episode of generalized dystonia. It is a life-threatening condition that may arise in the course of primary and secondary dystonic syndromes (7). Uncontrolled, this disorder can lead to serious complications such as, respiratory and renal failures. The majority of research demonstrates that DBS implantation shows favorable results in drug-resistant cases. However, only a few articles reported DBS use in young children, with the youngest reported age being 8 years old $(2,8)$. In performing DBS implantation in youngsters, there are possible limitations such as the potential growth of the brain, head and trunk, the small amount subcutaneous fat and the loose covering skin. Therefore, DBS is FDA approved for only patients of 7 years old and more.
In this report, the authors are presenting a 5-year-old boy with dystonic storm treated with DBS, making him the youngest patient treated with DBS to be reported. DBS implantation was considered as a last line life-saving treatment in this patient.

\section{CASE REPORT}

A 5-year-old boy with medical history of epilepsy and mental retardation who presented with dystonic storm is discussed in this case report. The patient was under treatment with Valproic acid $300 \mathrm{mg} /$ day with effective control of his epilepsy. Neurologic examination revealed generalized persistent dystonia with hyperactive deep tendon reflexes. Due to tense masseter muscles and nasopharyngeal dystonia oral intake was absent and therefore, nasogastric (NG) tube placement failed, and intravenous (IV) fluids and total parenteral 
nutrition (TPN) was started. Ophthalmologic examination was normal, with no iris and pupil pathologies. Brain computed tomography (CT) scan and magnetic resonance imaging (MRI) showed bilateral calcification located in the pallidum (Figure 1A-B). Complete blood count (CBC) revealed low hemoglobin levels $(9.7 \mathrm{gm} / \mathrm{dL})$ suggesting the necessity of iron replacement. Blood and urine biochemistries revealed no pathological findings with the normal levels of ammoniac, amino acids, ceruloplasmin, copper and hormones. Serologic tests and TORCH screening showed negative results. Lumbar puncture was performed for cerebrospinal fluid (CSF) analysis. Opening pressure, direct microscopic analysis, biochemistry, culture and serologic tests of the CSF were all normal. Electroencephalography (EEG) revealed central continuous sharp waves activity. Neuropsychological tests could not be administered to the patient due to his dystonicus state. However, before the presentation of the dystonic storm the patient was administered Denver II Developmental Test at the outpatient clinic where he was monitored. He showed performances of 3 months for personal-social interaction, 4 months for fine motor skills and 2 years for language. FahnMarsden Score was 106.

Treatment with Valproic acid $40 \mathrm{mg} / \mathrm{kg} /$ day was continued. Trials of oral Akineton $0.4 \mathrm{mg} / \mathrm{kg} / \mathrm{day}$, bolus IV Akeniton $10 \mathrm{mg} /$ day, IV midazolam infusion $40 \mathrm{mg} / \mathrm{kg} /$ day, L-Dopa $8.3 \mathrm{mg} / \mathrm{kg} /$ day, Carbamazepine $40 \mathrm{mg} / \mathrm{kg} /$ day, oral Baclofen $0.6 \mathrm{mg} / \mathrm{kg} /$ day and intrathecal (IT) baclofen infusion test with $50 \mathrm{mg} /$ day were carried out for the treatment of dystonia symptoms; however, all were found ineffective. Repeated injections of botulinum toxin-A into the left extremities, cervical and masseter muscles were performed; but they also were ineffective in reduction of the dystonic symptoms. The only effective intervention in controlling the dystonia was sedating the patient with prolonged continuous Midazolam infusion, which was considered a temporarily management and not appropriate as long-term treatment. For this reason, surgical treatment with DBS was decided to be utilized.
The surgical procedure was performed under general anesthesia using the Leksell (Elekta, Stockholm, Sweeden) stereotactic frame with a ring system. The surgical target was GPi and its position was localized anatomically by direct visualizing on T2-weighted and IR MRI. FrameLink 2.0 software (Medtronic, Inc., Minneapolis, MN) was used for applying CT-MR fusion technique and reformatted the MR image to the AC-PC plane to yield the calculated coordinates for the GPi, with the aid of Schaltenbrand and Wahren stereotactic atlas. Quadripolar electrodes (Model 3389, Medtronic, Minneapolis, MN, USA) were implanted bilaterally in GPi in a single session. The electrodes were directed venteromedially making their trajectory passing lateral and ending ventral to the calcifications. Electrode targeting was confirmed using microelectrode recordings (MER) demonstrating bursting neuronal patterns that are archetypal in dystonic patients. Keeping in mind the young age of the patient and the potential growth of the head, the distal ends of the electrodes we implanted $1 \mathrm{~cm}$ inferior to the targeted $\mathrm{GPi}$, with the trajectory of the electrode poles including the GPi. After the localization of GPi and the recording of the bursting patterns, the electrode was advanced more ventrally. Bursting pattern was followed during the advancement of the electrode until the appearance of a pattern of low noise and decreased background activity, which indicated the inferior end of the GPi. The electrode was the advanced more inferior to GPi with the final position of contact of 0 was inferior the GPi and the electrode tip venteroanterior to the calcifications. A dualchannel pulse generator (Kinetra Model 7428, Medtronic, Inc.) that is subclavicularly implanted to the right side of the patient's chest during the same operation was connected to the leads. No complication occurred during or after the surgery. Postoperative cranial CT scan was obtained in order to confirm the correct positions of the electrodes (Figure 2). The activation of the electrodes took place 3 days after the surgery. The stimulation parameters were $1.5 \mathrm{~V}, 130 \mathrm{~Hz}, 90 \mu \mathrm{s}$, with monopolar stimulation on contact 1 . Four weeks after the initiation of stimulation dystonia showed improvement

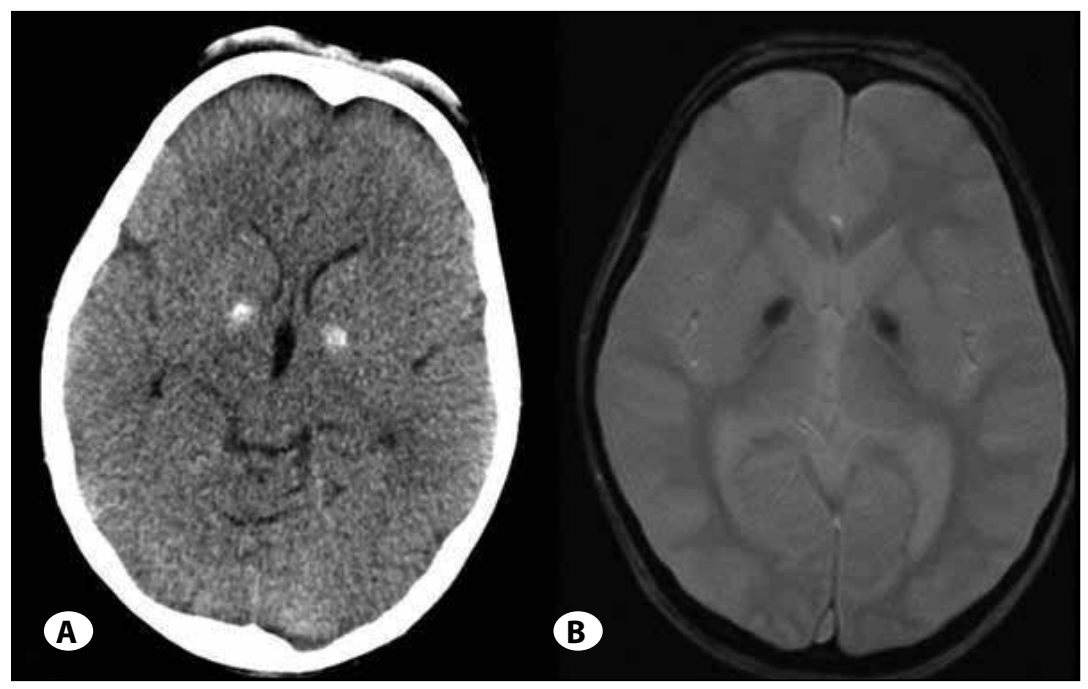

Figure 1: Cranial CT scan (A) and IR-weighted MRI (B) showing bilateral calcification located in pallidum. 


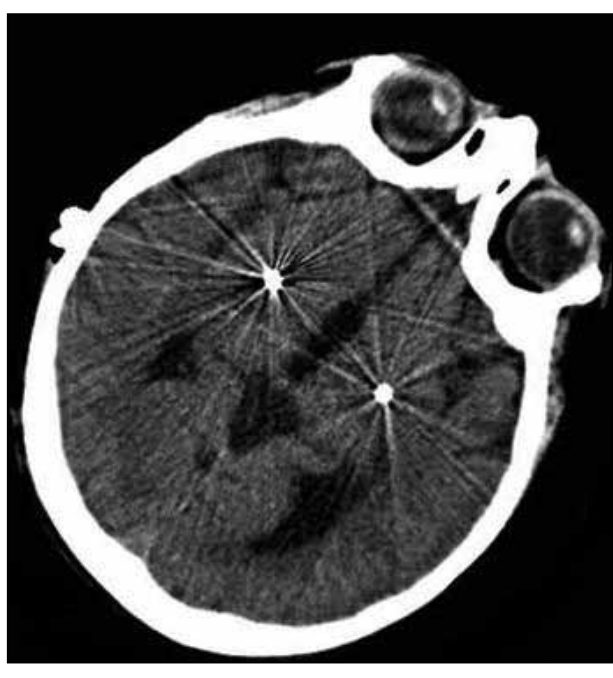

Figure 2: Postoperative cranial CT scan demonstrating the position of the electrodes tips in the GPi.

and sedation with Midazolam was stopped. The patient became more cooperative, oral intake was established and he could sit with support. Final stimulation adjustment was done 6 months after surgery with the parameters of 3.5V, 130 $\mathrm{Hz}, 90 \mu \mathrm{s}$. There were no side effects related to the stimulation. In the post-operative follow-ups, Fahn-Marsden Scores were found 64 (40\% reduction) at 6 months, 24 (77\% reduction) at 12 months and 20 ( $81 \%$ reduction) at 15 months. The final score was even better than the score of the state before the dystonic storm.

\section{DISCUSSION}

A dystonic storm, or status dystonicus, is a life-threatening condition which requires aggressive control; otherwise it may result in bulbar and ventilatory dysfunction resulting with the risk of aspiration pneumonia and respiratory failure, severe pain, and metabolic derangements such as acute renal failure and rhabdomyolysis (4). In our case, the dystonic storm was secondary to the pathological calcifications. As these calcifications are located in the pallidum, the dysfunction will result in the reduction of the activity along the putamenGPe connection and increase of the inhibition of the STN and GPi by GPe efferents (9). In spite of this possible mechanism, the certain pathophysiology of the disease is unknown. Cases of drug-resistant dystonic storm are reported to be well responding to surgical treatment, such as thalamotomy (7), bilateral pallidotomy (6), bilateral GPi DBS (11) and pallidotomy with GPi DBS (4). Radiofrequency ablation of the globus pallidus internus, or pallidotomy, result in removal of the inhibitory output from pallidum to the cortex (1). DBS of GPi has also been safely used for symptoms of dystonia in many different conditions $(4,14)$.

Previous reports show that surgical intervention has good results in cases of refractory dystonic storm. Our results in this specific case were also consistent with the previous literature. In addition, the patient in our case was a 5 year old, and to our best knowledge this is youngest patient to be treated with DBS mentioned in the literature. Other articles also reported treatment with DBS for young children, however, the age of the youngest patients was 8 years old $(2,8)$. The brain grows in size and volume considerably during the early years of life (3). Extensive brain development is believed to occur in the first 10 years, with increased rates between 3 to 6 years (12). Also, the functional development of the brain occurs early in life and continues to mature and develop into the teen years and perhaps beyond. Also, a child is physically smaller and will undergo several periods of physical growth $(5,13)$. For this reason, one must keep in mind if the device will provide the same physiologic fit, when implanted in a child as compared to an adult. If it does not, alternate techniques of implantation must be considered (10). In addition, the growth and development of adolescents, particularly in girls where procedures involving the chest may impact the development of breast buds. Also, less subcutaneous fat in a child may result in increased device erosion. Another important issue is the possibility that the child will outgrow the device. Thus, plans for revisions or device design changes must be considered (10). For the above reasons, FDA had approved the use of DBS for children of 7 years old and over (10).

In the present case, the patient presented with dystonic storm which was resistant to all modalities of medical treatment. As mentioned before, untreated cases carry high risk of mortality and morbidity, due to bulbar and ventilatory dysfunction with the risk of aspiration pneumonia and respiratory failure, severe pain, and metabolic derangements, such as acute renal failure and rhabdomyolysis (4). For this reason, using DBS for this patient was our last chance as a life-saving procedure. The young age of the patient and the potential growth of the head, the distal ends of the electrodes we implanted $1 \mathrm{~cm}$ inferior to the targeted GPi, with the trajectory of the electrode poles including the GPi was taken into consideration. There were no side effects related to the stimulation. The patient was relieved from the dystonic storm state and the dystonia showed improvement with $81 \%$ reduction of the total FahnMarsden score after 15 months of surgery, which was even better than the score of the patient before the dystonic storm. Despite the accepted general indications for DBS treatment, we believe that every candidate case must be evaluated independently on the basis of its own state.

\section{REFERENCES}

1. Balas I, Kovacs N, Hollody K: Staged bilateral stereotactic pallidothalamotomy for life-threatening dystonia in a child with Hallervorden-Spatz disease. Mov Disord 21:82-85, 2006

2. Coubes $P$, Echenne $B$, Roubertie $A$, Vayssière $N$, Tuffery $S$, Humbertclaude V, Cambonie G, Claustres M, Frerebeau P: [Treatment of early-onset generalized dystonia by chronic bilateral stimulation of the internal globus pallidus. Apropos of a case]. Neurochirurgie 45(2):139-144, 1999 (French)

3. Courchesne E, Chisum HJ, Townsend J, Cowles A, Covington J, Egaas B, Harwood M, Hinds S, Press GA: Normal brain development and aging: Quantitative analysis at in vivo $M R$ imaging in healthy volunteers. Neuroradiol 216:672-682, 2000 
4. Elkay M, Silver K, Penn RD, Dalvi A: Dystonic Storm due to Batten's Disease Treated with Pallidotomy and Deep Brain Stimulation. Mov Disord 24(7):1048-1053, 2009

5. Holland BA, Haas DK, Norman D, Brant-Zawadzki M, Newton TH: MRI of normal brain maturation. Am J Neuroradiol 7: 201-208, 1986

6. Kyriagis M, Grattan-Smith P, Scheinberg A, Teo C, Nakaji N, Waugh M: Status dystonicus and Hallervorden-Spatz disease: Treatment with intrathecal baclofen and pallidotomy. J Paediatr Child Health 40:322-325, 2004

7. Manji H, Howard RS, Miller DH, Hirsch NP, Carr L, Bhatia K, Quinn N, Marsden CD: Status dystonicus: the syndrome and its management. Brain 121:243-252, 1998

8. Maurtua MA, Cata JP, Martirena M, Deogaonkar M, Rezai A, Sung W, Lotto M, Niezgoda J, Schubert: Dexmedetomidine for deep brain stimulator placement in a child with primary generalized dystonia: Case report and literature review. J Clin Anesth 21(3):213-216, 2009

9. Mitchell IJ, Luquin R, Boyce S, Clarke CE, Robertson RG, Sambrook MA, Crossman AR: Neural mechanisms of dystonia: Evidence from a 2-deoxyglucose uptake study in a primate model of dopamine agonist-induced dystonia. Mov Disord 5:49-54, 1990
10. Peña C, Bowsher K, Samuels-Reid J: FDA-approved neurologic devices intended for use in infants, children, and adolescents. Neurology 63(7):1163-1167, 2004

11. Teive HA, Munhoz RP, Souza MM, Antoniuk SA, Santos ML, Teixeira MJ, Barbosa ER, Carvalho RC, Scaff M, Werneck LC: Status Dystonicus: Study of five cases. Arq Neuropsiquiatr 63:26-29, 2005

12. Thompson PM, Giedd JN, Woods RP, MacDonald D, Evans AC, Toga AW: Growth patterns in the developing brain detected by using continuum mechanical tensor maps. Nature 404:190-193, 2000

13. van der Knaap MS, Valk J, Bakker CJ, Schooneveld M, Faber JA, Willemse J, Gooskens RH: Myelination as an expression of the functional maturity of the brain. Dev Med Child Neurol 33:849-857, 1991

14. Zorzi G, Marras C, Nardocci N, Franzini A, Chiapparini L, Maccagnano E, Angelini L, Caldiroli D, Broggi G: Stimulation of the globus pallidus internus for childhood-onset dystonia. Mov Disord 20:1194-1200, 2005 